\title{
Designing a School based Health Education Program to Prevent Nutritional Anaemia among the Adolescent Girls in a Rural School in Bangladesh
}

\section{Md. Tarek Hossain ${ }^{1}$ and Sharmin Khan Luies ${ }^{2}$}

${ }^{1}$ Universal Health Coverage, Health System and Population Studies Division, icddr,b, Dhaka, Bangladesh

${ }^{2}$ Nutrition Program Evaluation Unit, Nutrition and Clinical Services Division, icddr, b, Dhaka, Bangladesh

\begin{abstract}
In Bangladesh, the nutritional status of adolescents is reprehensible, where a large number of adolescent girls are suffering from malnutrition. Among others, anaemia is currently one of the most common and intractable nutritional problems that may develop at any stage of the life cycle but children, adolescent girls and women of reproductive age are high-risk groups for developing anaemia. Although the situation of anaemia among adolescents has improved over the past few years, the current magnitude of the problem in both urban and rural areas is clearly a significant public health concern for the country. Therefore, a specific health education program on nutritional anaemia will be beneficial to sensitize adolescent girls on related topics and also contribute to self-care and behavior change, therefore, improve their quality and value of life.
\end{abstract}

Keywords: Nutrition; Anaemia; Public health; Bangladesh

\section{Background}

Nutrition is vital for good health and nutritional status is an important health indicator to assess health status and morbidity patterns of a country. There were an estimated 1.2 million adolescents aged 1019 years, which is $19 \%$ of the total population of the world facing a series of serious nutritional challenges, especially in the developing countries [1]. In Bangladesh, there are 27.7 million adolescents aged 10-19 years, where 13.7 million girls and 14 million boys making up about one fifth of the total population [2]. The nutritional status of adolescents in the country is reprehensible, where a large number of adolescent girls are suffering from malnutrition.

In past few decades, there has been a general decrease in the prevalence of severe malnutrition in the country; still, the prevalence is higher among the girls compared to boys. Short maternal height is accounted for a substantial number of low birth weight babies ( 2.5 kilograms); those are subsequently more susceptible to infections and death in infancy [3]. Survivors grow up as undernourished adults and giving rise to an intergenerational cycle of undernourishment. In addition, small pelvis size may also cause obstructed labor due to cephalopelvic disproportion (CPD) [4]. For girls, its associated health consequences range from ill health (from chronic morbidity due to infections of the reproductive system and conditions such as vesicovaginal fistula) to death during and after childbirth [3].

Among others, anaemia, defined as hemoglobin concentration below established cut-off levels [5]; is currently one of the most common and intractable nutritional problems globally [6]. It is a global public health problem that affects both developed and developing countries and has adverse effects on health as well as social and economic development [7]. An estimate of World Health Organization (WHO) shows that the number of anaemic people worldwide to be a staggering two billion with approximately $50 \%$ of all anaemias is attributable to iron deficiency [5,7]. Adolescent nutrition is important to the health of girls and is relevant to maternal nutrition. In Bangladesh, adolescent girls suffer from one or more forms of malnutrition including low birth weight, wasting, stunting, underweight, Vitamin A deficiencies, iodine deficiency disorders and anaemia. The situation appears to be worse in girls than boys, where 3.9 million adolescent girls are suffering from anaemia [8]. Although the situation of anaemia among adolescents has improved over the past few years, the current magnitude of the problem in both urban and rural areas is clearly a significant public health concern for the country.

\section{Knowledge of Nutrition}

In Bangladesh, low family income, education and periodic food shortage were associated with inadequate dietary intake [9], which might have led to under nutrition. Dietary knowledge and access to resources are critical in improving health and nutrition in a sustainable way. It has appeared that knowledge of nutrition among rural adolescent girls is poor and they are generally unaware of the need of consuming healthy quantities of foods such as fish, meat, eggs, milk, vegetables and fruits during pregnancy and lactation [10].

\section{Food Requirements}

A study conducted among the female guardians (mothers of adolescents) revealed that $43.1 \%$ guardians mentioned of the requirement of more food for boys than girls, $19.4 \%$ indicated that girls need more food and $37.5 \%$ mentioned that the requirement is the same for both. Those, who mentioned the need of more food for girls included the following reasons: i) girls will stay with parents for less time as they will go to in-laws; ii) wear and tear on the body due to pregnancy and childbirth; iii) blood loss during menstruation; iv) more physical activity/housework; v) need for good health/nutrition;

*Corresponding author: Md. Tarek Hossain, Research Investigator, Universa Health Coverage, Health System and Population Studies Division, icddr,b, Dhaka Bangladesh, Tel: 8801912147121; E-mail: tarek.hossain@icddrb.org

Received June 08, 2017; Accepted September 24, 2017; Published October 25 2017

Citation: Hossain MT, Luies SK (2017) Designing a School based Health Education Program to Prevent Nutritional Anaemia among the Adolescent Girls in a Rural School in Bangladesh. J Health Educ Res Dev 5: 229. doi:10.4172/2380-5439.1000229

Copyright: (c) 2017 Md. Tarek Hossain, et al. This is an open-access article distributed under the terms of the Creative Commons Attribution License, which permits unrestricted use, distribution, and reproduction in any medium, provided the original author and source are credited. 
and vi) having more health problems than boys [3]. Another study demonstrated that the prevalence of severe thinness of urban adolescent girls is about $22 \%$ in low-income families, whereas in rural adolescent girls it is about $10 \%$. Nutritional status of adolescent girls belongs to low-income families are found poor in both urban and rural areas of the country [11]. A substantial variation in dietary intakes exists, depending on socioeconomic status and urban/rural residence. Levels of food insecurity also related to under nutrition in adolescent girls and adult women [12].

\section{Deficiency Disease}

Anaemia in adolescents is a serious cause of concern as it can negatively and irreversibly affect cognitive, motor and behavioral development with long-term implications for learning, scholastic achievement and earnings. In Bangladesh, four national nutrition surveys (1962/64, 1975/76, 1981/82 and 1995/96) have been conducted to investigate the prevalence of anaemia among different population groups. Since the second survey (1975/76), the average national prevalence of anaemia has not fallen; $74 \%$ found anaemic (64\% in urban areas and $77 \%$ in rural areas) in $1995 / 96$. A recently published study revealed a higher prevalence of anaemia among the adolescent girls (10-19 years), where $51.6 \%$ girls were suffering from any form of anemia [13]. Anaemia makes adolescent girls and women weaker during pregnancy and delivery, increasing their risk of prolonged labor and reducing their chances of surviving due to blood loss during and after childbirth. It also lowers their work capacity, productivity and causes fatigue, making them less able to engage in social activities and to nurture and care for their families [8].

\section{Health Profile of Adolescents}

Bangladesh is one of the signatory countries of the UN Convention on the Rights of the Children (the development, survival, protection and participation rights of children) [14], yet to achieve wide acknowledgement and realization of these rights. The barriers to realizing these rights are more prominent in rural areas and in other vulnerable sections of the society. Poor nutritional status in early life of the women and associated cultural practices reduces learning potential of the women, eventually increases reproductive and maternal health risks and lowers their productivity [15]. Gender discrimination and imbalanced distribution of food within the family is a primary underlying cause of South Asia's (including Bangladesh) persistent high rates of malnutrition compared with other developing countries [16]. Gender based violence is still prominent in the country and adolescent girls frequently fall victim to these harmful practices in both public and private life. Lack of proper guidance to avoid exploitation, negligence and discrimination in childhood gradually makes adolescent girls vulnerable and push them into the lifelong downward spiral of deprivation and exclusion from mainstream society. Adolescent girls mobility is often restricted; therefore, they lose their friends and freedom that limit their opportunities to value their life [17]. It also marks the end of many girls formal education, as they expected to devote their full time to domestic chores in their in-laws [18].

Adolescent girls are in a period of rapid physical, sexual and emotional development. For about five to six years of their life, most of them suffer from various emotional and psychological problems such as fear, confusion, doubts and anxieties due to physical change with the development of the primary and secondary sex characteristics along with the maturation of reproductive functioning. Due to lack of information on physical change and reproductive health, they have a hard time coping with such problems. Anaemia poses a threat to the girl's life that has lifelong consequences, an additional burden for the nutritional interventions.

In our country, we have the cultural variations according to the time and geographic locations and to ensure gender equity and reduce discrimination in nutritional intake, there is a crucial need to work in this sector with the government and non-government organizations. This would take time to change, meanwhile; we need to take specific intervention targeting adolescent girls living in rural areas considering the magnitude of the problems. A study has found that "socioeconomic and health intervention programs have a positive impact on nutritional status and survival" [19]. Therefore, a specific health education program on nutritional anaemia can further improve the nutritional status of adolescent girls thus will improve their value of life.

\section{Steps of Planning of Health Education Program}

Careful planning is essential to the success of health education program to prevent nutritional anaemia among the adolescent girls in Bangladesh. A series of sequential steps need to be followed for developing a realistic and effective health education program in this context (Figure 1).

\section{Step 1: Collection baseline data and information}

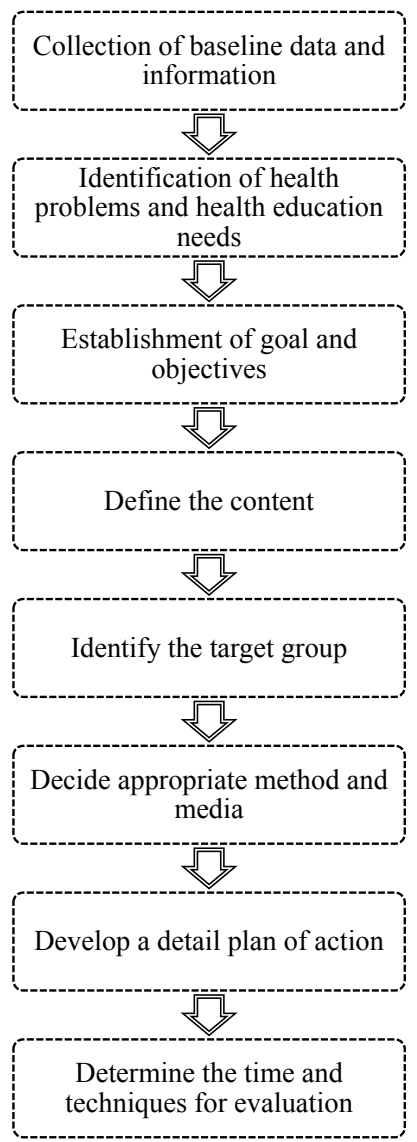

Figure 1: Steps of planning a health education program 
Citation: Hossain MT, Luies SK (2017) Designing a School based Health Education Program to Prevent Nutritional Anaemia among the Adolescent Girls in a Rural School in Bangladesh. J Health Educ Res Dev 5: 229. doi:10.4172/2380-5439.1000229

Page 3 of 5

Baseline data and information are very important for planning an appropriate and effective health education program. Baseline information includes are vital statistics, status of nutritional knowledge, status of health knowledge, attitude and behavior, socio economic status (SES), demographic patterns etc. It has the potential to be based on the existing evidence and available literature. As illustrated in different pieces of literature, nutritional anaemia is a growing and inherited health problem in developing countries especially in adolescent group (10-19 years). Bangladesh has been facing this problem for a long since and now a day this problem has become very challenging because of its adverse consequences on health and economic development. It causes varying degrees of health problem and finally, it may end up with death. A recent study revealed on an average $51.6 \%$ adolescent girls are suffering from any forms of nutritional anaemia in our country [13]. Therefore, it can be realized that nutritional anaemia is a significant and challenging health problem for rural adolescent girls in the country.

In the baseline, necessary data can be collected from followings:

- Community survey;

- School based survey;

- Local health authorities e.g., community clinic, union health and family welfare centre etc. (public sector);

- NGOs providing health services.

\section{Step 2: Identification of health problems and health education needs}

Based on available information and baseline data, we have to prioritize the health problems and identify the areas (specific geographic location such as village) which are more prone to nutritional anaemia and prepare a description of the situation by person, place and time.

\section{Step 3: Establishment of goal and objectives}

a) Program goal: Provide health education to prevent nutritional anaemia among the adolescent girls (10-19 years) in the selected area of Bangladesh.

b) Program objectives: General objective is to provide health education through a school based intervention to prevent nutritional anaemia among the adolescent girls in a rural school in Bangladesh.

Specific objectives

- To educate about the importance of nutrition for preventing nutritional anaemia;

- To introduce with the food varieties (sources of vitamins, minerals, iron etc.);

- To teach the causes and consequences of nutritional anaemia and

\begin{tabular}{|c|c|c|c|c|c|}
\hline Time and Groups & Objectives & $\begin{array}{l}\text { Method and } \\
\text { Media }\end{array}$ & $\begin{array}{l}\text { Degree of } \\
\text { attainment }\end{array}$ & Resources & Remarks \\
\hline $\begin{array}{l}\text { G 1: } \mathbf{3 0} \\
10: 00-11: 00 \mathrm{am} \\
\text { G 2: } \mathbf{3 0} \\
\text { 11:15-12:15 pm } \\
\text { G 3: } \mathbf{3 0} \\
01: 30-02: 30 \mathrm{pm} \\
\text { G 4: } \mathbf{3 0} \\
02: 45-03: 45 \mathrm{pm} \\
\text { G } \mathbf{5}: \mathbf{3 0} \\
04: 00-05: 00 \mathrm{pm}\end{array}$ & $\begin{array}{l}\text { - Students will be able to understand the } \\
\text { function of nutrition and the magnitude } \\
\text { and impact of nutritional anaemia in } \\
\text { Bangladesh }\end{array}$ & $\begin{array}{l}\text { Lecture; } \\
\text { participatory open discussion } \\
\text { Laptop and projector; } \\
\text { flipchart; marker; poster and } \\
\text { picture demonstration }\end{array}$ & $95 \%$ & $\begin{array}{l}\text { Resource persons and } \\
\text { logistics }\end{array}$ & $\begin{array}{l}\text { Conduct instant } \\
\text { evaluation } \\
\text { (Ensure presence } \\
\text { of the targeted } \\
\text { students) }\end{array}$ \\
\hline
\end{tabular}

Table 1: Country background, nutrition and importance of nutrition in body function.

\begin{tabular}{|c|c|c|c|c|c|}
\hline Time and Groups & Objectives & $\begin{array}{l}\text { Method and } \\
\text { Media }\end{array}$ & $\begin{array}{l}\text { Degree of } \\
\text { attainment }\end{array}$ & Resources & Remarks \\
\hline $\begin{array}{l}\text { G 1: } \mathbf{3 0} \\
\text { 10:00-11:00 am } \\
\text { G 2: } \mathbf{3 0} \\
\text { 11:15-12:15 pm } \\
\text { G 3: } \mathbf{3 0} \\
01: 30-02: 30 \mathrm{pm} \\
\text { G 4: } \mathbf{3 0} \\
02: 45-03: 45 \mathrm{pm} \\
\text { G 5: } \mathbf{3 0} \\
\text { 04:00-05:00 pm }\end{array}$ & $\begin{array}{l}\text { - Students will be able to describe } \\
\text { nutritional anaemia, sign and } \\
\text { symptoms of nutritional anaemia } \\
\text { - Students will be able to know } \\
\text { the causes and associated factors } \\
\text { responsible in developing nutritional } \\
\text { anaemia }\end{array}$ & $\begin{array}{l}\text { Lecture; participatory open } \\
\text { discussion; } \\
\text { video documentary; group } \\
\text { exercise } \\
\text { Laptop and projector; } \\
\text { flipchart; marker; poster and } \\
\text { picture demonstration }\end{array}$ & $95 \%$ & $\begin{array}{l}\text { Resource persons and } \\
\text { logistics }\end{array}$ & $\begin{array}{l}\text { Conduct instant } \\
\text { evaluation } \\
\text { (Ensure presence } \\
\text { of the targeted } \\
\text { students) }\end{array}$ \\
\hline
\end{tabular}

Table 2: Definition of nutritional anaemia, Sign and symptoms of nutritional anaemia, Causes of nutritional anaemia.

\begin{tabular}{|c|c|c|c|c|c|}
\hline Time and Groups & Objectives & $\begin{array}{l}\text { Method and } \\
\text { Media }\end{array}$ & $\begin{array}{l}\text { Degree of } \\
\text { attainment }\end{array}$ & Resources & Remarks \\
\hline $\begin{array}{l}\text { G 1: } \mathbf{3 0} \\
10: 00-11: 00 \mathrm{am} \\
\text { G 2: } \mathbf{3 0} \\
11: 15-12: 15 \mathrm{pm} \\
\text { G 3: } \mathbf{3 0} \\
01: 30-02: 30 \mathrm{pm} \\
\text { G 4: } \mathbf{3 0} \\
02: 45-03: 45 \mathrm{pm} \\
\text { G 5: } \mathbf{3 0} \\
\text { 04:00-05:00 pm }\end{array}$ & $\begin{array}{l}\text { - Students will be able to explain } \\
\text { the effect of nutritional anaemia on } \\
\text { health }\end{array}$ & $\begin{array}{l}\text { Lecture; } \\
\text { participatory open discussion; } \\
\text { video documentary; group } \\
\text { exercise } \\
\text { Laptop and projector; } \\
\text { flipchart; marker; poster and } \\
\text { picture demonstration }\end{array}$ & $95 \%$ & $\begin{array}{l}\text { Resource persons and } \\
\text { logistics }\end{array}$ & $\begin{array}{l}\text { Conduct instant } \\
\text { evaluation } \\
\text { (Ensure presence } \\
\text { of the targeted } \\
\text { students) }\end{array}$ \\
\hline
\end{tabular}

Table 3: Consequences and effects of nutritional anaemia on adolescent girls (10-19 years). 
Citation: Hossain MT, Luies SK (2017) Designing a School based Health Education Program to Prevent Nutritional Anaemia among the Adolescent Girls in a Rural School in Bangladesh. J Health Educ Res Dev 5: 229. doi:10.4172/2380-5439.1000229

Page 4 of 5

- To inform different strategies for the prevention of nutritional anaemia.

\section{Step 4: Define the content}

For the school-based health education program content will be followings.

- Country background, nutrition and importnce of nutrition in body function;

- Definition of nutritional anaemia;

- Sign and symptoms of nutritional anaemia;

- Causes of nutritional anaemia;

- Consequences and effects of nutritional anaemia on adolescent girls (10-19 years);

- Food and nutrition, understanding the food group pyramid;

- Food variety and healthy diet (sources of vitamins, minerals, iron etc.);

- Importance of balanced and varied meals;

- Personal hygiene and sanitation;

- Deworming and management of other infectious diseases;

- Anaemia as public health problem and strategies to prevent nutritional anaemia.

\section{Step 5: Identify the target group}

Adolescent girls aged 10-19 years, who are studying at class five to ten in a selected school in the particular area.

\section{Step 6: Decide appropriate method and media}

Method: Lecture, participatory open discussion, video documentary and group exercise.
Media: Laptop and projector, flipchart, marker, poster and picture demonstration.

\section{Step 7: Develop a detail plan of action}

Duration of the program: One week (5 days).

Number of students: 150 (five groups, thirty girls in each group).

Setting: A rural school from the selected district in Bangladesh.

Resources: Resource persons, finance and materials (logistics).

As an example, a detailed plan with content has been illustrated in the tabular format (Table 1 to Table 5).

\section{Step 8: Determine the time and techniques for evaluation}

Evaluation is the systematic assessment of the worth or merit of some object. As World Health Organization (WHO) defines, "An evaluation is an assessment, as systematic and impartial as possible, of an activity, project, program, strategy, policy, topic, theme, sector, operational area, institutional performance" [20]. In this proposed program, the evaluation will be conducted by the following ways:

I. Question answer session after completing each content (instant evaluation); and

II. Comparing the students level of knowledge by a self-administered questionnaire focusing on the educational component of the program.

a. Before starting the program. b. After completion of the program.

\section{Conclusion}

Health education is educating people about health; thus, motivates one to improve and maintain their health, prevent disease and reduce risky behaviors. School based nutrition education has potential to improve dietary practices that affect young persons' health, growth, and intellectual development. This health educational intervention will enhance adolescent girl's knowledge, skills and support to build

\begin{tabular}{|c|c|c|c|c|c|}
\hline Time and Groups & Objectives & $\begin{array}{l}\text { Method and } \\
\text { Media }\end{array}$ & $\begin{array}{l}\text { Degree of } \\
\text { attainment }\end{array}$ & Resources & Remarks \\
\hline $\begin{array}{l}\text { G 1: } \mathbf{3 0} \\
10: 00-11: 00 \mathrm{am} \\
\text { G 2: } \mathbf{3 0} \\
\text { 11:15-12:15 pm } \\
\text { G 3: } \mathbf{3 0} \\
01: 30-02: 30 \mathrm{pm} \\
\text { G 4: } \mathbf{3 0} \\
\text { 02:45-03:45 pm } \\
\text { G 5: } \mathbf{3 0} \\
04: 00-05: 00 \mathrm{pm}\end{array}$ & $\begin{array}{l}\text { - Students will be able to know the } \\
\text { importance of nutrition } \\
\text { - Students will be able to identify } \\
\text { foods under different food groups }\end{array}$ & $\begin{array}{l}\text { Lecture; } \\
\text { participatory open discussion; } \\
\text { video documentary; group } \\
\text { exercise } \\
\text { Laptop and projector; } \\
\text { flipchart; marker; poster and } \\
\text { picture demonstration }\end{array}$ & $95 \%$ & $\begin{array}{l}\text { Resource persons and } \\
\text { logistics }\end{array}$ & $\begin{array}{l}\text { Conduct instant } \\
\text { evaluation } \\
\text { (Ensure presence } \\
\text { of the targeted } \\
\text { students) }\end{array}$ \\
\hline
\end{tabular}

Table 4: Food and nutrition, understanding the food pyramid, Food variety and healthy diet (sources of vitamins, minerals, iron, etc.).

\begin{tabular}{|c|c|c|c|c|c|}
\hline Time and Groups & Objectives & $\begin{array}{l}\text { Method and } \\
\text { Media }\end{array}$ & $\begin{array}{l}\text { Degree of } \\
\text { attainment }\end{array}$ & Resources & Remarks \\
\hline $\begin{array}{l}\text { G 1: } \mathbf{3 0} \\
\text { 10:00-11:00 am } \\
\text { G 2: } \mathbf{3 0} \\
\text { 11:15-12:15 pm } \\
\text { G 3: } \mathbf{3 0} \\
\text { 01:30-02:30 pm } \\
\text { G 4: } \mathbf{3 0} \\
\text { 02:45-03:45 pm } \\
\text { G 5: } \mathbf{3 0} \\
04: 00-05: 00 \mathrm{pm}\end{array}$ & $\begin{array}{l}\text { - Students will be understand the } \\
\text { importance of balanced meals } \\
\text { - Students will be able to ensure } \\
\text { personal hygiene and combat } \\
\text { against worm and infectious } \\
\text { diseases } \\
\text { - Students will be able to know and } \\
\text { apply the strategies for prevention of } \\
\text { nutritional anaemia }\end{array}$ & $\begin{array}{l}\text { Lecture; } \\
\text { participatory open discussion; } \\
\text { video documentary; group } \\
\text { exercise } \\
\text { Laptop and projector; } \\
\text { flipchart; marker; poster and } \\
\text { picture demonstration }\end{array}$ & $95 \%$ & $\begin{array}{l}\text { Resource persons and } \\
\text { logistics }\end{array}$ & $\begin{array}{l}\text { Conduct instant } \\
\text { evaluation } \\
\text { (Ensure presence } \\
\text { of the targeted } \\
\text { students) }\end{array}$ \\
\hline
\end{tabular}

Table 5: Importance of balanced and varied meals, Personal hygiene and sanitation, Deworming and management of other infectious diseases, Anaemia as public health problem and strategies to prevent nutritional anaemia. 
Citation: Hossain MT, Luies SK (2017) Designing a School based Health Education Program to Prevent Nutritional Anaemia among the Adolescent Girls in a Rural School in Bangladesh. J Health Educ Res Dev 5: 229. doi:10.4172/2380-5439.1000229

Page 5 of 5

positive attitudes towards preventing nutritional anaemia. It is also important to conduct these sessions with a regular interval with updated content and diversified methodologies that respect regional and local characteristics. School authorities, community leaders and parents must engage and commit to implementing and sustaining nutrition education program within the school. Such support is crucial to promoting healthy behaviors. Health education through school based intervention proposed here employed methods that favored dialogues, exchange of experiences and reflection on the student's own practices from their previous experiences. This interdisciplinary approach will be beneficial to sensitize adolescent girls on related topics and also contribute to self-care and behavior change, therefore, improve their quality and value of life.

\section{Acknowledgements}

This paper is been developed based on the work done in the course of 'Health Education, Rights and Ethics (MPH-5023)' of Master of Public Health (MPH) program at American International University-Bangladesh (AIUB). The authors are currently working in icddr,b and gratefully acknowledge core donors for their support and commitment to icddr,b's research efforts includes: Government of the People's Republic of Bangladesh; Global Affairs Canada (GAC); Swedish International Development Cooperation Agency (Sida) and the Department for International Development (UK Aid).

\section{Authors' Contributions}

TH conceptualized and designed the intervention and drafted the first version of the manuscript. Both authors participated in critical revision of the manuscrip and contributed to its intellectual improvement. Final draft was prepared by $\mathrm{TH}$. Both authors went through the final draft and approved it for submission.

\section{References}

1. Kotecha PV, Patel S, Baxi RK, Mazumdar VS, Misra S, et al. (2009) Reproductive health awareness among rural school going adolescents of Vadodara district. Indian J Sex Transm Dis 30: 94-9.

2. The United Nations Children's Fund Website (2017) Bangladesh.

3. Brkat A, Majid M (2003) Adolescent and youth reproductive health in Bangladesh status, issues, policies, and programs. POLICY Project of USAID.

4. Liselele BH, Boulvain M, Tshibangu CK, Meuris S (2000) Maternal heigh and external pelvimetry to predict cephalopelvic disproportion in nulliparous African women: A cohort study. BJOG: An International Journal of Obstetrics \& Gynaecology 107: 947-952.

5. WHO, UNICEF (2001) Iron deficiency anaemia: assessment, prevention, and control: A guide for programme managers. World Health Organization NHD/01.3.

6. Sah PJ, Patil BA, Yadav N, Hunskatti K, Sharma A (2014) The association between iron deficiency anaemia and intellectual capacity in adolescent school students. IJHSR 4: 123-128.

7. WHO (2015) The global prevalence of anaemia in 2011. Geneva: World Health Organization.

8. IPHN (2007) National strategy for anaemia prevention and control in Bangladesh. Institute of Public Health Nutrition, Directorate General of Health Services, Ministry of Health and Family Welfare 11-17.

9. Abdullah M, Wheeler EF (1985) Seasonal variations, and the intra-household distribution of food in a Bangladeshi village. Am J Clin Nutr 41: 1305-1313.

10. Alam N, Roy SK, Ahmed T, Ahmed SMA (2010) Nutritional status, dietary intake, and relevant knowledge of adolescent girls in rural Bangladesh. J Health Popul Nutr 28: 86-94.

11. Akhter N, Sondhya YF (2013) Nutritional status of adolescents in Bangladesh: Comparison of severe thinness status of a low-income family's adolescents between urban and rural Bangladesh. J Educ Health Promot 2: 27.

12. Ahmed T, Mahfuz M, Ireen S, Ahmed AM, Rahman S, et al. (2012) Nutrition of children and women in Bangladesh: trends and directions for the future. Health Popul Nutr 30: 1-11.

13. Mistry KS, Jhohura TF, Khanam F, Akter F, Khan S, et al. (2017) An outline of anemia among adolescent girls in Bangladesh: findings from a cross-sectional study. BMC Hematology 17: 13

14. The United Nations Human Rights Website (2017) Convention on the Rights of the Child.

15. Oniang'o R, Mukudi E (2002) Nutrition and gender. A Foundation for Development, Geneva.

16. Quisumbing RA (2008) Women's status and the changing nature of rura livelihoods in Asia. Reducing Poverty and Hunger in Asia. International Food Policy Research Institute 15: 1-4.

17. UNICEF (2010) Women and girls in Bangladesh. The United Nations Children's Fund.

18. Ambrus A, Field E (2008) Early marriage, age of menarche and female schooling attainment in Bangladesh. Journal of Political Econ 116: 881-930.

19. Choudhury KK, Hanifi MA, Rasheed S, Bhuiya A (2000) Gender inequality and severe malnutrition among children in a remote rural area of Bangladesh. $J$ Health Popul Nutr 18: 123-130.

20. WHO (2013) Evaluation practice handbook. World Health Organization 